が生ずるのはエネルギーピーク設定時に閏題があるので はないかと考え, ${ }^{99 \mathrm{~m}} \mathrm{Tc}$ 線源を用い線源の大きさ, 強度, 位置を変化させ検討した結果，カメラ中心より $40 \%$ 以内 では線源の大きさによる影響は認められなかった．線源 強度については，線源の大きさが小さい場合にずれが大 きく, 大きくなるにつれ小さくなる傾问を示し, 線源の 大きさは $6.0 \mathrm{~cm}$ 以上は必要と言える. またウインドを 表示スペクトルの中心に設定するより少し下側に設定し た方が感度, 均一性が良い場合もあり, 使用する装置の ホトマル特性に合ったエネルギー設定が必要ではないか と考える.

\section{3. 自作ピンホールコリメータによる RI 画像評価}

愛媛大学医学部附属病院放射線部 ○渡部真二・中田 茂・上田幸之 田頭裕之・伊達卓二・川上寿昭

〔目的〕 ${ }^{201} \mathrm{~T} 1$ にる心筋等をピンホールコリメータ で撮影する場合に付属のピンホール $(4.5 \mathrm{~mm} \phi)$ では感 度が低いため撮影に長時間を要した. そこで自作のピン ホール 2 個 $(6 \mathrm{~mm} \phi, 7 \mathrm{~mm} \phi)$ を作製しそれぞれのピンホ ールにおける像の拡大, 丕み, 感度, 均一性および MTF を比較検討した。

〔結果】昖大はピンホールの直径には無関係で幾何学 的な挔大だけであった。感度は $6 \mathrm{~mm} \phi$ で約 1.5 倍, 7 $\mathrm{mm} \phi$ で約 2.3 倍になりピンホールの面積に比例してい る.MTF はピンホールの直径が大きくなるにつれて畏 化しボケが直径に比例している. 歪みは中心を通る軸に 刘して平行方向の半值幅が周辺で小さくなるために起こ るととがわかった. 均一性は距離の逆 2 乗で補正すると とによって改善した。

\section{RI イメージングカメラとフィルム特性}

島根医科大学附属病院中央放射線部

○高橋司伸・氐平武樹 笠井俊文・君野勝治

ガンマカメラで少られる像は，人体から放出される 線の位置と強度 (カウント数) の分布をイメージャを通 し，フィルム上に濃度差として表現したあのである。 診断能の高い画像を得るには， $r$ 線の強度分布を忠実に 黒化度分布として表現するととが大切である。今回情報 を忠実に表現するフィルムを選択する目的で基礎的実験 を行った．実験の結果，感度及びコントラストに扣いて は雨面乳剤である RX が優れており, 解像力は $\mathrm{OM}-1$ が非常に優れていた．総合的な評価を行うため ROC 曲 線による比較を験い OM-1が良い棓価を得た。フィル 厶選択においてはフィルムの特性を充分考慮し検査の目
的にあったフィルムを使用すべきである.

\section{5. シンチカメラの性能検査について}

国立浜田病院放射線科

○小重行・原田 悟・伊藤正人

当院の $\Sigma 410 \mathrm{~S}$ の常に拈ける均一性検査として $\mathrm{NE}$ MAに準じた方法を行った. データ処理による画像評価 法も検討した. データ処理能力上 1 ピクセルに1023カウ ントしか収集できず，正確な値は望めないが CFOVで 積分均一性士6. $4 \%$, 微分均一性 $\pm 4.5 \%$, 点線源感度 10\%となった. 積分, 微分均一性之も5 分以内で処理で き日常の管理に適しており，また画像上にそれらの位置 を図示，ヒストグラムを書かせる等によって，PMTの 変動の大きい位置, カウントの分布状態等, 具体的に評 倠できた。

\section{座長集約}

演題52では, シンチカメラの線源の強度, 大きさ, 位 置等によるエネルギーピークの変化についての報告であ り, カメラ視野の大型化, オペレーションのオート化と いう動向のなかで日常留意しなければならないと思われ る.カメラ個々のエネルギーピークのとり方の問題点む あろうが今後の臨床面への発展を期待したい.

演題53では, 自作ピンホールコリメータによる画像評 侕の報告である. 谷口（広島大医）より，小さく撮像し て電気的に拡大 (1.5倍) することの意義とピンホール自 体の精度についての質問があったが，乙れについては各 施設においての目的の相違, 並びにデータ処理システム の性能等にあよると思われる。

演題54では, RIイメージカメラの画像情報に対する 各種フィルムの特性報告である. 地味ではあるがわれわ れが日常業務を行う上で重要な実験であろう。一方, 各 フィルムメーカのフィルムと現像処理との組合せによる 特性の変化ということも考えてみたい

演題55では, シンチカメラの均一性について, 現在の ポラロイド等視覚によるチェックにかわるあのとして, データ処理による数量的チェックに対する評価報告であ る. シンチカメラがコンピュータ化されつつある今日, 均一性向上への一つの方向性を示すものであろうと思わ れる。

\section{基礎放射線技術学一器材 II-}

\section{座長 中瀬節夫（香川医科大学病院）}

56. 高密度グリッドと標準グリッドの物理特性と画像検 討

愛埈大学病院放射線部

○吉本政弘・高須賀章・筧川憲二 